\title{
Genre as Implicit Methodology in a Collaborative Writing Initiative
}

\author{
GILLIAN LAZAR * \\ EDDIE ELLIS \\ Middlesex University
}

Received: 1 February 2010 / Accepted: 26 March 2010

\begin{abstract}
It is often assumed that the academic genres taught by EAP specialists at universities are fixed and stable, provide easily accessible exemplars for student writers and feature in programmes running prior or parallel to the students' courses. This paper describes a collaborative writing initiative in which these assumptions were challenged. A writing specialist collaborated with a team of academics on a Post-graduate Certificate of Education (PGCE) in order to improve students' writing of a Masters-level assignment. While the writing specialist was implicitly committed to a genre-based teaching methodology, this was necessarily framed in terms of the aims of the PGCE academics, who were particularly concerned about improving student understanding of both assignment guidelines and assessment criteria. An impact study detailing positive outcomes for this collaboration, suggests that a genre-aware pedagogy can still inform a programme for writing within the disciplines even when the focus on genre is implicit.
\end{abstract}

\section{KEYWORDS:}

Academic genres, assignment guidelines, assessment criteria.

\section{RESUMEN}

Con frecuencia se asume que los géneros académicos que los especialistas en IFA enseñan en las universidades son fijos y estables, que existen modelos accesibles para los alumnos, y que se presentan en cursos previos. Este trabajo describe una iniciativa de redacción colaborativa en la que tales supuestos se ponen en tela de juicio. Un especialista en redacción colaboró con un equipo de académicos en un Post-graduate Certificate of Education $(P G C E)$ con el fin de mejorar la redacción de los estudiantes en trabajos a nivel de Master. Mientras que el especialista se encargaba implícitamente de una metodología de enseñanza basada en géneros, ésta se encontraba enmarcada en los objetivos de los académicos del PGCE, quienes se preocupaban especialmente por hacer entender las pautas y criterios de evaluación. Los resultados positivos de esta colaboración sugieren que la enseñanza del género puede guiar un curso de redacción dentro de una disciplina aún cuando no esté enfocada en el género implícitamente.

\section{PALABRAS CLAVE:}

Géneros académicos, pautas de evaluación, criterios de evaluación.

\footnotetext{
*Address for correspondence: Gillian Lazar. Centre for Learning and Teaching Enhancement, Trent Park, Bramley Road, Oakwood, N14 4YZ London, England. Tel: 0208 4116578, E-mail: G.Lazar@mdx.ac.uk Eddie Ellis. Department of Education, School of Art and Education. Tel: 0208 4116536, E-mail: E.Ellis@mdx.ac.uk
} 


\section{INTRODUCTION}

In recent years, there has been an upsurge of research into academic genres (see for example Bhatia, 1993; Feak and Swales, 2009; Johns, 1997; Hyland, 1990; Hyland, 2004a; Swales, 1990; Swales and Feak, 1994; Swales and Feak, 2000). Genre is seen as "a term for grouping texts together, representing how writers typically use language to respond to recurring situations" (Hyland, 2004b: 4). Thus, the work of genre analysis lies in identifying which types of texts are typical of academic writing, and how they can be grouped together. Some of the most common genres focused on have included abstracts (Bhatia, 1993), research papers (Swales \& Feak, 1994) and literature reviews (Feak \& Swales, 2009).

According to Bhatia (1993), the analysis of different genres can take place at three different levels. These include the lexico-grammatical, text-patterning and structural interpretation (Ibid: 24), which will be discussed in more detail further on. The role of the EAP specialist/writing teacher is to use the data from genre analysis to develop a syllabus and materials which familiarise students with the different types of genres that they might encounter while undertaking their academic courses. The work of identifying and analysing these academic genres involves collaboration with subject lecturers as specialist informants (Ibid: 34). On the whole, it is often assumed that the course developed by writing teachers will run parallel to the academic courses that the students are following, or may precede it as is the case with pre-sessional courses generally offered at British universities. It is also often assumed that the genres being investigated and subsequently taught are relatively fixed and well-established, whereas it may be that many writing teachers and their students are grappling with genres that are "shifting and variable" (Hyland, 2004b: 37). These genres frequently emerge from the evolving conventions and specialised knowledge of a particular discourse community (Ramanathan \& Kaplan, 2000).

This paper describes a teaching context at Middlesex University, London, UK in which both of these assumptions were challenged. Firstly, rather than working in parallel to an academic course, the work of the writing teacher was embedded more centrally in a programme for Post-graduate Certificate in Education (PGCE) students, undertaking the one year training necessary to become secondary school teachers in the UK. This paper will describe the varying profile of these students, the writing problems identified by their lecturers, and the highly collaborative programme that was developed between the writing specialist and the academics responsible for delivering the PGCE programme. This collaboration involved a close interaction between two distinct disciplinary communities, that of the EAP/writing specialist and that of the Education lecturers working on the PGCE programme, both of whom had their own epistemologies, methodologies and aims. While the writing teacher was implicitly committed to a genre-based approach to teaching writing, this was necessarily framed in terms of the methodology and aims of the PGCE lecturers, as will be described in this paper. 
Secondly, with regards to the genre of assignments on the course, it was decided to focus the collaboration on a single assignment, called 'From Rhetoric to Reality'. From the point of view of the writing lecturer, this genre did not conform strictly to any of the genres previously described in the EAP literature. Instead, it could be conceptualised as a hybrid genre, developed by PGCE academics to meet the specific institutional constraints and expectations (Bhatia, 1993) of the teaching context. This paper will describe how the context informed both the development of this genre as well as the collaboration between the writing teacher and the PGCE academics. This collaboration enabled students to become more confident in tackling the writing of the hybrid genre and helped to improve their standard of writing.

\section{THE CONTEXT}

\subsection{The course and student profile}

The Post-graduate Certificate in Education (PGCE) programme at British universities is a one year programme for post-graduates wishing to train as either primary or secondary school teachers. Typically, students on this programme spend a total of 60 days on a university campus, attending lectures and seminars. They also spend 120 days on placements in secondary schools, where they not only observe lessons, but also teach up to $60 \%$ of a qualified teacher's contact hours. While doing so, they are overseen by a mentor, who is a subject specialist at the school. While on campus, students are taught mainly in the subject groups for their speciality, whether it is Science, English, Physical Education (PE) or Modern Foreign Languages. Thus, a key aim of the programme is to produce secondary school teachers who are pedagogically sound subject specialists, capable of a high level of reflective practice.

The students enrolled on the Middlesex University programme are very diverse. Not only do they come from a wide range of disciplinary backgrounds, they are also from a range of ethnic and linguistic backgrounds. In terms of disciplinary background, during their first degrees some of the students may not have encountered the type of academic writing required on the PGCE. For example, some mathematics graduates may not have had to write a long academic essay. In addition, a number of students do not speak English as their first language, particularly those training as Modern Foreign Languages teachers. Thus, when students embark on the course it cannot be assumed that they will all automatically have the same skills necessary for undertaking written assignments at post-graduate level.

Over a number of years, PGCE staff expressed increasing concern about the writing skills of their students, and called on a writing specialist located in English Language and Learning Support (ELLS), now known as the Learner Development Unit or LDU ${ }^{1}$. One of the remits of the Learner Development Unit is to provide guidance and support to help students 
across the university develop their English language and academic writing proficiency. Initially, the LDU lecturer went into some individual subject groups and delivered a one-hour session, focusing on areas which had been identified by PGCE lecturers as weaknesses in the academic writing of their students. These included understanding the assignment title; key elements of making an effective academic argument; structuring and organising an assignment; referencing and academic style. It was felt, however, that this session had limited effectiveness as students were not always able to transfer the generic skills to the specifics of the assignment they were required to produce.

Subsequently, it was decided to link the input of the writing teacher to one particular assignment, known as R2R (from Rhetoric to Reality). This enabled the work of the writing lecturer to be properly embedded within the PGCE programme, thus standardising the type of support for academic writing given to all PGCE students.

\subsection{The $R 2 R$ assignment}

The 'From Rhetoric or Reality' (R2R) assignment brief was developed partly in response to the institutional constraints and expectations of the teaching context, as described by Bhatia (1993). In 2006 the PGCE elected to be a qualification aligned with the National Framework for Higher Education Qualifications' (FHEQ) Descriptor at M (Masters) level. It was thus imperative that the written assignments for students reached an appropriate post-graduate standard. While there is often some difficulty about defining precisely what M-level means, the Middlesex University Level Descriptor for Master's level defines it in the following way:

"Learning accredited at this level will reflect the ability to: display mastery of a complex and specialised area of knowledge and skills, employing advanced skills to conduct research, or advanced technical or professional activity, accepting accountability for related decision making, including use of supervision" (Level Descriptors: Guidance on the Characteristics and Context of Learning, Middlesex University).

This level descriptor equates to the Master's level descriptor of the National Framework for Higher Education, which also includes these qualities and transferable skills necessary for employment: "the exercise of initiative and personal responsibility; decision-making in complex and unpredictable situations; and the independent learning ability required for continuing professional development" (The Framework for Higher Education Qualifications in England, Wales, and Northern Island, August 2008).

It was therefore decided by PGCE academics that the main assignment undertaken by the students should be a 5000 word piece of writing, described as follows:

"The assignment is a small scale research project where the theoretical background of the issue is investigated and then primary research into the practice observed in the school experience setting is conducted" (PGCE Secondary Programme Handbook 2008 - 2009). 
This type of assignment was felt to be appropriate for the course as it would demonstrate the requisite post-graduate research skills, while simultaneously enabling trainee teachers to reflect critically on the application of theory to the classrooms in which they were doing their teaching practice. Clear links might therefore be demonstrated between higherorder research skills (one of the features of post-graduate writing) and the reflection on classroom practice (one of the essential characteristics of a well-qualified secondary school teacher).

\section{METHOD}

\subsection{Use of documentation for R2R assignment}

Genre analysis is generally undertaken by collecting a corpus of texts typical of that genre and then subjecting them to systematic scrutiny, in which core similarities between the texts are noted as generic features (Bhatia, 1993: 23-24; Swales, 2001: 16). These similarities might include frequency of particular syntactic properties (Bhatia, 1993: 25), or patterns of rhetorical moves, as in Swales (1981). In many cases, the genre analysis is undertaken on texts written by 'expert' writers, who are well versed in the conventions of the particular genre. These genres are then presented to students as 'models' of good writing, even though students may not be able to replicate them due to their communicative or linguistic deficiencies (Marshall in Flowerdew 2000: 370). Flowerdew (2000), therefore, points out that there are a number of advantages in exposing students to good 'apprentice' generic exemplar, including student exemplars from lecturers. For instance, these exemplars replicate the end product required more accurately than any version by an expert writer, thus proving more attainable and therefore more motivating for students.

In the case of the R2R assignment, one of the key aims of the lecturers was to pioneer best practice in meeting the University's aspirations expressed through its Enhancing Learning Teaching and Assessment (ELTA) Strategy in order to enhance the assessment experience for Middlesex students on innovative programmes leading to improvements in student achievement. One of the important principles to have been adopted is that assessment should inform, reinforce and be embedded in student learning. Assessment designed to create feedback (or feedforward) for students about their learning is known as formative assessment (Irons 2008:7) and the initial stages in the assessment process were designed to provide students with formative feedback to accelerate their learning.

It was decided that the use of an exemplar assignment would be one plank in the strategy to embed formative feedback in the programme. This exemplar would necessarily be an example of student writing, since the genre under discussion was largely newly-invented to meet institutional needs, and hence did not correspond exactly to any exemplars by 'expert' writers. One difficulty from the point of view of the writing specialist was that there was no 
corpus of assignments to analyse, as this assignment had only run for one year and all work, except for the exemplar, had been returned to students. Thus, it was not possible to undertake a genre analysis in the usual way. Furthermore, the PGCE lecturers believed that it would prove more beneficial for students to analyse a text which was not a particularly good model. This chosen text demonstrated some serious weaknesses in both content and rhetorical structure, but it was felt that critical discussion of these flaws would be useful for the students. However, it was agreed that the text used for analysis was less an exemplar (i.e. a model to aim for) than a sample (an example to subject to critical scrutiny).

It was agreed that one way of subjecting the sample to critical appraisal was by asking students to apply the assessment criteria to the sample assignment in order to 'mark' it. This would address one of the major concerns of the PGCE lecturers: that the assessment criteria, and indeed the assignment guidelines themselves, were not always sufficiently transparent for students. The writing specialist was aware that a significant problem with assignment guidelines and marking criteria is that often students do not fully understand what these mean, particularly if they make use of terms such as 'analyse', 'critique' and 'reflect' which presuppose a comprehension of cognitive processes central in university study. It seemed to make sense, therefore, to focus on making the assignment guidelines and marking criteria clearer to students, while simultaneously linking these to the sample assignment. At the same time, it was hoped that the generic features of an assignment of this nature would be made more explicit for the students.

The writing specialist therefore undertook a detailed analysis of both the assignment guidelines and the assessment criteria that were given to students in the Programme Handbook. In the assignment, students were expected to research a generic area of education in which they were interested relating to one of three topics: Classroom Management, Inclusion for $\mathrm{All}^{2}$ and Learning and Teaching Styles. Students were advised to select an area prominent in the school in which they were based so that they would have easy access to the necessary information. The assignment guidelines then provided the students with detailed three-page guidance as to what should be included in each of the eight separate sections of the assignment. For example, the guidance for the first three sections was as follows:

\section{Section 1: The Issue}

What do you understand by this topic?

Outline why you have selected the area you have chosen. Which Teaching Standards is this issue associated most strongly with and why? What interests you about it? Is it an issue in your school? What did you know before you started this report? How do the media portray the issue? 


\section{Section 2: The Theory}

In theory what should happen in this area of education? Use secondary data, government policy/guidelines and literature to explain the ideal that should happen in school.

\section{Section 3: The Focus}

What key questions/hypotheses will your investigation hope to answer? Identify smaller areas of the large issue given to investigate.

(PGCE Secondary Programme Handbook, Middlesex University 2008/2009, pages 47-48).

These three sections were then grouped together and mapped to the assessment criteria in the following way:

\begin{tabular}{|l|l|}
\hline Assessment Criteria & Key questions \\
\hline $\begin{array}{l}\text { The justification and discussion show a } \\
\text { systematic understanding and a critical }\end{array}$ & Is choice of topic is justified from a \\
variety of perspectives? \\
practice. & $\begin{array}{l}\text { Is the theory explained with reference to } \\
\text { the literature? } \\
\text { Are selected quotes used effectively? }\end{array}$ \\
\hline
\end{tabular}

(Ibid, page 55).

For the writing specialist, it seemed that there was an implicit link between the assignment guidelines, the assessment criteria and the concept of rhetorical moves. Each section of the assignment could be seen as embodying different possible rhetorical moves, with different communicative intentions each time. Thus, for example, the assignment guidelines for Section 1 could be said to encompass the following 'moves':

- Establish the research field by selecting a particular topic

- Justify the selection of this choice with reference to teaching standards, your own personal interest and whether this choice is an issue at your school.

While there is not sufficient space within this article to provide a detailed breakdown of the different 'moves' for each section, it is clear that the assignment guidelines implicitly encoded certain rhetorical 'moves' which were then implicitly reinforced in the assignment guidelines. The writing specialist was committed to a genre-based pedagogy, but was mindful of the fact that the preoccupations of the PGCE lecturers needed to be addressed. Therefore, any input by the writing specialist had to address the concern that students had difficulty in fully understanding the assignment guidelines and assessment criteria. However, as the guidelines and criteria implicitly encoded different genre 'moves', deconstructing them for students would highlight the cognitive processes in the text realised through different rhetorical moves. 


\subsection{Initial stages of collaboration}

The collaboration between the writing specialist and the PGCE lecturers encompassed a number of different stages.

To begin with, the writing specialist attended the marking standardisation meeting for PGCE lecturers. During this meeting, the PGCE academics used the marking criteria for the assignment to 'mark' the sample essays, thus reaching a consensus about how and why the sample would be graded at a certain level. As a 'new' genre, individual subject leaders had slightly different expectations about what was required, and these expectations were discussed in the meeting. For the writing specialist, this provided interesting insights into the content, organisation and register required, as well as some of the disciplinary differences between members of the team. For example, the lecturer training students to teach Art was less concerned with displaying data from the assignment in different ways (e.g. by means of pie charts or bar graphs) than his colleagues from Maths or Science. By being included in these discussions, the writing specialist was able to observe the process whereby a provisional genre became clearly delineated and institutionally ratified.

The next stage of the collaboration involved a 1.5 hour lecture given by the writing specialist to all PGCE students. The same lecture was repeated four times with four different groups of students with roughly 70-80 students in each group. The content of the lecture was as follows:

a) The assessment criteria for each section of the assignment were decoded for students by explaining academic meta-language, i.e. terms such as justification, discuss, systematic understanding and critical awareness. Where possible, concrete examples from the sample assignment of such terminology in action were provided.

b) Students were then asked to apply these criteria and the accompanying key questions to the sample assignment in order to 'mark' the relevant section of it. Discussion about this was undertaken in pairs before feedback in a plenary with the whole group.

c) During the plenary, the writing specialist highlighted certain extracts of text from the sample, and these were then discussed in detail in terms of whether they met the assessment criteria or not. Strengths and weaknesses in the extract were identified.

d) Students were given clear practical guidelines about how to tackle particular sections of the assignment. For example, for Sections 1-3, the following advice was given:

1. Identify an area of interest in your school.

a. Read, summarise and synthesise: academic journals, journalism, government documents such as the Curriculum and Strategy, school policies, etc. 
b. Formulate a research question which allows you to investigate how the Rhetoric is being played out at your school.

This lecture was notable for a number of reasons. In the first place, all PGCE academics were present in the lecture attended by the students studying their subject area. This kind of team teaching has been recommended in developing the academic writing competence of nursing and midwifery students (Giménez, 2008a). In this case, while the writing specialist delivered the lecture, there was ample opportunity for the academics to contribute to the lecture, either reinforcing or disagreeing with the viewpoint expressed by the writing specialist. This enabled the writing specialist to incorporate the perspectives of 'specialist informants' in a manner that was transparent to the students. It also opened up potential areas of discussion about disciplinary differences between different subjects on the PGCE programme. Thus, rather than presenting the final assignment as a static piece of writing rigidly circumscribed by the assessment criteria, the incorporation of different perspectives by lecturers enabled students to experience the genre as dynamic and creative.

Secondly, when evaluating the writing sample, the writing specialist encouraged students to apply the concept of rhetorical moves. For example, when the assessment criteria were applied to the first section, students were asked whether or not the choice of research topic had been adequately justified in terms of teaching standards, personal interest or a school issue. They were asked to identify where in the text this move was made, and it was suggested to them that a competent assignment would include this move. In some parts of the assignment, certain moves were clearly absent, and this resulted in serious weaknesses in coherence and cohesion, which students were able to critique. In fact, the sample assignment provided students with a realistic model to evaluate, and helped to train them to peer assess each other's work, an activity that formed part of the follow up to the lecture and helped to underpin the process of formative assessment.

\subsection{Follow up stages of collaboration}

Following on from the lecture, once students had written a draft of their assignment, they were asked in pairs to peer assess each other's work, this time under the supervision of their PGCE lecturers, rather than the writing specialist. This peer assessment not only helped to reinforce many of the points made in the lecture, but also enabled students to engage in an iterative process of reflection about their work; a skill key in the training of teachers. This peer assessment concentrated, however, on the overall structure of the assignment by using the assessment criteria.

Flowerdew (2001) notes that approaches to genre are divided into those grounded in the textual, at one end of the spectrum, and those grounded in the context or the community situation at the other. Approaches grounded in the context or community situation characterise genre as a "means of using communication to achieve certain ends" (Swales, 2001). This 
approach was fore-grounded when working with Middlesex PGCE students and lecturers as it emphasised the communicative purpose of the assignment and linked clearly with the lecturers' aims of developing a coherent formative assessment on the programme. It also aligned well with a group of students who were either native speakers of the language or were close to native speaker-like proficiency. Nevertheless, it was recognised that a minority of students could also benefit from guidance in the lexico-grammatical patterning of the genre, since they were non-native speakers who may not have a more intuitive grasp of the appropriate vocabulary and grammar to employ in order to produce the requisite 'moves'. In order to cater for this group, 28 face-to-face individual tutorials were offered with the writing specialist, each one lasting between 30-60 minutes. The focus in these sessions tended to be on micro-features of language use, such as appropriate lexical phrases or the functional language used for highlighting particular rhetorical moves in a specific section of the assignment. Students were also given feedback on areas of grammatical or lexical difficulty.

Finally, the writing specialist participated in an online discussion board, using the university's Virtual Learning Environment. This enabled students to express any concerns or ask any further questions relating to the assignment.

\section{RESULTS}

The collaborative model was evaluated in two ways. Firstly, student feedback was gathered through the dissemination of questionnaires. A total of 148 responses were analysed. $95 \%$ of students expressed approval that the lecture was pitched at the right level and that it was clear and helpful. $100 \%$ of students said that their understanding of assessment criteria had improved. In response to open-ended questions, 13 students commended the use of a sample assignment, 13 were positive about the use of examples from the assignment to illustrate more general points and 8 commented positively about the 'step by step' guide of what to do for each section. On the other hand, two students felt it would have been better if the PowerPoint presentation accompanying the lecture had been more visual and less text-heavy, while 15 students felt that the lecture was too long (Ellis 2010).

In terms of student performance, overall the number of students gaining grades 1 and 2 increased by $13 \%$, as can be seen below: 


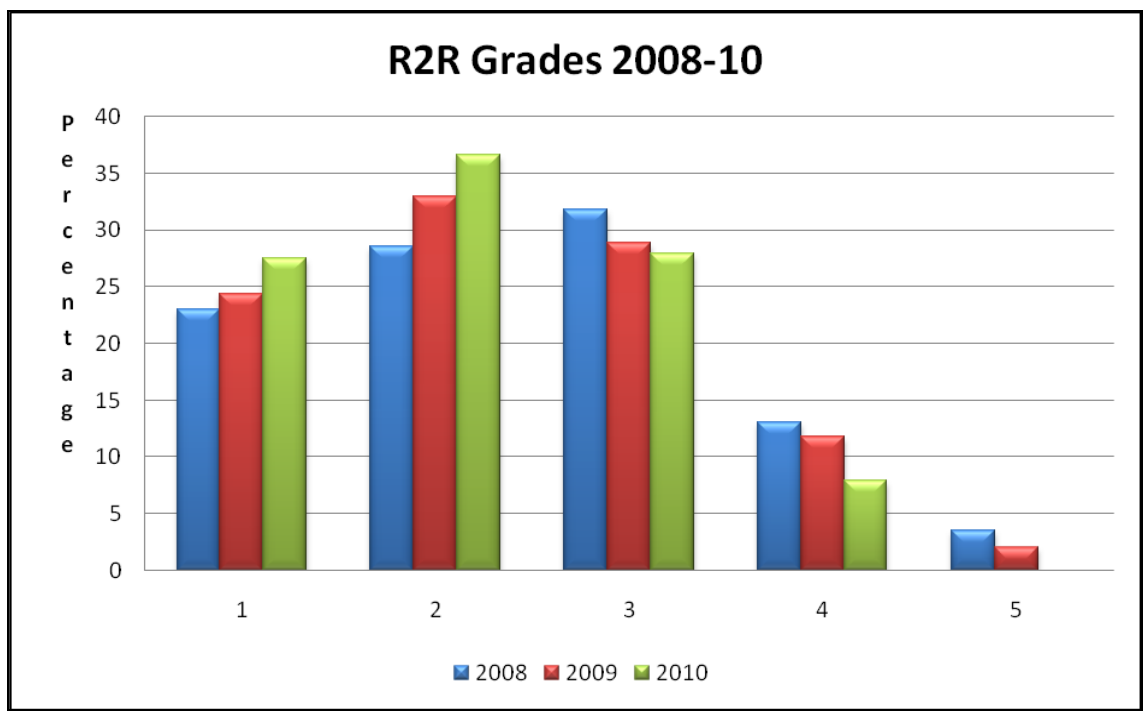

Figure 1. Students' grades.

This data suggests that the collaborative model described significantly impacted on student learning and achievement. Nevertheless, it raises a number of issues about the use of genre as a teaching tool for teachers of writing in further and higher education.

\section{DISCUSSION AND CONCLUSIONS}

It is clear from the collaboration which has just been described that many writing assignments used for assessment purposes cannot always be delimited in terms of existing descriptions of particular genres. Instead, such genres arise from a complex interaction of institutional and pedagogic factors, and are constantly evolving and developing in response to these. In addition, there may not be any good examples of the genre available for analysis. One reason for this is that academics might be reluctant to release 'good' examples for fear that they will be plagiarised. Another reason is that " $(. .$.$) it is often very difficult for students to obtain and$ identify highly regarded instances of texts without access to confidential information, such as the level of grade the piece of writing was awarded (...)"(Paltridge, 2001). This means that many student writing assignments become a kind of occluded genre (Swales, 1996) in that students are expected to produce the genre without ever having seen an exemplar of it. In this situation, the only sources of information available to students are the assignment brief/rubric and assessment criteria if these are available, which is not always the case.

A collaborative programme of teaching and writing support between writing specialists and subject academics could be an effective way of addressing some of these issues. The writing specialist can be given full access to the ongoing processes of genre development, 
such as providing feedback on initial drafts of assignment guidelines and assessment criteria, or attending meetings to standardise marking. This privileged access can enable the writing specialist to draw extensively on the knowledge gained from specialist informants, i.e. the subject lecturers. If members of both these disciplinary communities are present at lectures or other teaching sessions, students are given the opportunity to establish core features of the genre under consideration, as well as to consider how these might be creatively adapted, for example to meet the demands of a particular subject area or the particular perspective of the writer.

Moreover, in the absence of a corpus for analysis, assignment rubrics or guidelines and assessment criteria often imply important features of the genre, which can then be identified for students. This is best done by applying these to an exemplar/sample text if possible. In the case of the PGCE programme at Middlesex University, the assignment guidelines provided a clear overall structure for the assignment, subsequently reinforced in the assessment criteria. This focus on overall structure enabled the writing specialist to direct the students towards a structural analysis of the sample text, focusing on core rhetorical moves. This would suggest that this kind of scaffolding by academics could usefully form a key part of assignment guidelines, particularly if the assignment has been specially devised to meet the needs of a local context. While there has been some research into the generic features of feedback given to student writers (see for example Hyland, 1998; Hyland \& Hyland, 2001), and on the relationship between genre and assessment criteria in assignments for nursing and midwifery students (Giménez, 2008b), perhaps future work could focus more systematically on the relationship between genre, assignment briefs and assessment criteria. In the absence of good exemplars, deconstructing assignment briefs and assessment criteria with students could potentially become a useful, if indirect, way of focusing on genre.

This focus on genre from a structural perspective is particularly beneficial when the majority of students in a group are native speakers of a language. Nevertheless, as has been mentioned, there is also scope for work at the lexico-grammatical level, particularly for those students who may not have the requisite fluency in micro-level language features, such as the lexical phrases or collocational combinations needed to make certain rhetorical moves.

From the EAP perspective, the positive outcomes in the Impact Study suggest that a genre-based pedagogy can inform a programme of 'writing for different disciplines' (Coffin and Hewings, 2003), even when the focus on genre is implicit rather than explicit, and is framed in terms that are meaningful for non-EAP staff from other disciplines.

\section{ACKNOWLEDGEMENTS}

We would like to thank our colleagues on the PGCE programme at Middlesex University for their support of the collaborative initiative described in this paper. 


\section{NOTES}

${ }^{1}$ Morbi Until September 2010, English Language and Learning Support (ELLS) was part of Learning Resources at Middlesex University. It is now part of the Learner Development Unit, Centre for Learning and Teaching Enhancement.

${ }^{2}$ In the British context the term Inclusion means the inclusion of children with Special Educational needs; gifted children and children who speak English as a second language within mainstream schools.

\section{REFERENCES}

Coffin, C. \& A. Hewings (2003). Writing for different disciplines. In C. Coffin \& M.J. Curry, S. Goodman, A. Hewings, T.M. Lillis, J. Swann (Eds.), Teaching Academic Writing: A Toolkit for Higher Education (pp. 45 - 72). London: Routledge.

Ellis, E. (2010). Embedding support for academic writing within the teaching and formative assessment processes linked to producing the 'Rhetoric to Reality' assignment. Impact Study within the Middlesex University Secondary Self Evaluation Document 2010.

Feak, C. \& Swales, J.M. (2009). Telling a Research Story: Writing a Literature Review. Michigan:

University of Michigan Press.

Flowerdew, L. (2000). Using a genre-based framework to teach organizational structure in academic writing. English Language Teaching Journal, 54 (4), 369 - 378.

Flowerdew, J. (2001). Genre in the classroom: A linguistic approach. In A. Johns (Ed) Genres in the classroom. Mahweh, New Jersey: Erlbaum. The Framework for Higher Education Qualifications in England, Wales, and Northern Island, August 2008, Quality Assurance Agency (QAA) for Higher Education. Retrieved online at: http://www.qaa.ac.uk/academicinfrastructure/FHEQ/EWNI08/default.asp\#p4.4 on 24/11/2010.

Giménez, J. (2008a). Beyond the academic essay: Discipline-specific writing in nursery and midwifery. Journal of English for Academic Purposes, 7(3), 151-164.

Giménez, J. (2008b). Academic Writing in Nursing: Genres, Marking Criteria and Course Design. The Asian ESP Journal, 4 (2). Retrieved online at: http://www.asian-espjournal.com/July_2008_jg.php on 30/11/2010.

Hyland, K. (1990). A Genre Description of the Argumentative Essay. RELC Journal, 21 (1), 66 - 78.

Hyland, F. and Hyland, K. (2001). Sugaring the pill: Praise and criticism in written feedback. Journal of Second Language Writing, 10 (3), 185-212.

Hyland, F. (1998). The impact of teacher written feedback on individual writers. Journal of Second Language Writing, 7(3), $255-286$.

Hyland, K. (2004a). Graduates' gratitude: the generic structure of dissertation acknowledgements. English for Specific Purposes, 23 (3), 303 - 324.

Hyland, K. (2004b). Genre and second language writing. Michigan: University of Michigan Press.

Irons, A. (2008). Enhancing Learning through Formative Assessment and Feedback. Abingdon: Routledge.

Johns, A. (1997). Text, role and context. Cambridge: Cambridge University Press.

Level Descriptors: Guidance on the Characteristics and Context of Learning, Middlesex University. Retrieved online at: http://www.mdx.ac.uk/aboutus/Strategy/regulations/moduleleveldescriptors.aspx on 30/11/2010

Paltridge, B. (2001). Linguistic Research and EAP Pedagogy. In J. Flowerdew \& M.Peacock (Eds.), Research Perspectives on English for Academic Purposes. (pp. 55-70). Cambridge: Cambridge University Press.

PGCE Secondary Programme Handbook (2008 - 20009). Retrieved from www.londonmentors.net/mus on 10/09/2008.

Ramanathan, V., \& Kaplan, R. B. (2000). Genres, authors, discourse communities: Theory and application for (L1 and) L2 writing instructors. Journal of Second Language Writing, 9(2), 171191. 
Swales, J.M. (1981). Aspects of Article Introductions. Birmingham: Aston University, Language Studies Unit.

Swales, J.M. (1990). Genre analysis: English in academic and research settings. Cambridge: Cambridge University Press.

Swales, J.M. \& C. Feak (1994). Academic Writing for Graduate Students: A course for non-native speakers of English. Michigan: University of Michigan Press.

Swales, J.M. (1996). Occluded genres in the academy: The case of the submission letter. In E.Ventola and A.Maurenen (Eds) Academic Writing: Intercultural and Textual Issues (pp 45-58). Amsterdam: John Benjamins.

Swales, J.M. \& C.Feak (2000). English in today's research world: A writing guide. Michigan: University of Michigan Press.

Swales, J. M. (2001). EAP-related linguistic research: An intellectual history. In J. Flowerdew, J. and M. Peacock (Eds.), Research Perspectives on English for Academic Purposes (pp 42-54). Cambridge: Cambridge University Press. 